\title{
China's Image and Public Diplomacy through Cultural Activity: Case Study on Summer Camp Program by Confucius Institute in Malang, Indonesia
}

\author{
T D Effendi ${ }^{1}$, S M Deniar ${ }^{2}$ \\ ${ }^{1,2}$ Universitas Muhammadiyah Malang \\ \{tonny@umm.ac.id ${ }^{1}$, Shannazdeniar@umm.ac.id²
}

\begin{abstract}
This article discusses China's image development through cultural activity by the Confucius Institute in Indonesia. It focuses on the impact of summer camp program held by Confucius Institute or Pusat Bahasa Mandarin (Mandarin Language Center) in State University of Malang to the participant's perception toward China. It is qualitative research where data collected by online survey and interview toward summer program participants. The informants are students of the international relations department at the University of Muhammadiyah Malang who joined the program. The concept of public diplomacy was used to explain the impact of the summer camp program on China's image. The result shows that the summer camp program seems to succeed to improve China's image and confirmed its image as a developed country in the economy. It also succeeds to engage participants for a study about China and study in China. However, most of the participants are not eager to write a thesis about China. Cultural activity through the summer camp program shows the success story of China's public diplomacy to develop China's positive image. However, it needs improvement, especially to encourage participants to write research about China.
\end{abstract}

Keywords: Public Diplomacy, Culture, Confucius Institute, China, Indonesia.

\section{INTRODUCTION}

China has become the world's second largest economic power after the United States. This position makes China become an important country in international relations today. However, it is not always getting a positive response from other countries, but also emerging criticism. These phenomena make China tries to explain its economic development will not a threat to other countries. Even China promotes economic cooperation with other countries. In this context, diplomacy becomes important for China to get a good impression. Public diplomacy is the best choice for China to develop its positive image where cultural activity is the central [1] which is dominated by traditional culture [2].

The Chinese government is trying to build a positive image by introducing their culture. In this context, language becomes important for China's public diplomacy [3]. Language is important where the Chinese language or Mandarin follows its economic raising to becomes lingua franca in trade [4]. Although it may difficult to replace English as the global language, at least, through Mandarin teaching program, it can be recognized as one of the global 
language [5]. However, in a certain country like the United States, the language program sometimes meets with misperception, when it is associated with economic, politic and ideology [6]. To meets with that occasion, the Chinese government established the Confucius Institute. Confucius Institute is an agency of the government of China to introduce Chinese culture around the world. Confucius Institute answers for the increasing of the number of Chinese culture and language learner as the impact of China's rising economy. In other words, the Confucius Institute may be related to China rise, a tool of image development through cultural activity [7], China's public diplomacy [8] and soft power [9].

Confucius Institute was established in 2004 and Chinese language education is the main focus. In 2009, the Confucius Institute has offered 9.000 Mandarin courses followed by approximately 260.000 participants. The Confucius Institute has also held about 7.500 cultural exchange program with 3 million participants. The Confucius Institute takes cooperation with the local university or high school. There are two types of Confucius Institute program overseas. They are the Confucius Institute and Confucius Classroom. The differences among those two types are related to its capacity and programs, where Confucius Classroom is smaller than Confucius Institute, but it aims to support Confucius Institute activities. Currently, there are 126 Confucius Institute in Asia, 59 in Africa, 160 in America, 182 in Europe and 21 in Oceania. The expansion of Confucius Institute around the world shows the importance of language and culture in China's public diplomacy [10] although it also could be viewed as China's aggressiveness in cultural promotion [11]. However, Confucius Institute also faces some problems like teaching materials, teacher, teaching methods and the negative perception such as cultural invasion [12]. In the relative similar work, Wu Ying examines the Confucius Institute's strategy for disseminating Chinese Culture by emphasizing in four factors as the aspect of Chinese culture, international cultural order, methods, channels, and mechanism in cultural dissemination and the result [13].

Since 2010, there are 6 Confucius Institutes were established in Indonesia. However, Pusat Bahasa Mandarin or Mandarin Language Center is the official name of the institute. The Confucius Institute has been established at the State University of Malang (established in 2010 under cooperation with Guangxi Normal University), State University of Surabaya (established in 2011 under cooperation with the Central China Normal University), Al Azhar University (established in 2011 under cooperation with Fujian Normal University), Maranatha Christian University (established in 2011 under cooperation with Hebei University), the University of Tanjungpura (established in 2011 under cooperation with Guangxi Universities for Nationalities) and University Hasanudin (established in 2011 under cooperation with Nanchang University). The establishment of Confucius Institute in Indonesia is not an easy way for Chinese government since there are some sensitive issues related with China which sometimes it affects in the institute's activity in the local level [14]. Therefore Confucius Institute in Indonesia is important to reducing China's negative image, however, it may in limited number, particularly to the people who engaged with the institute [15]. China has its attraction through Chinese diaspora and export, even before the Confucius Institute was established [16]. Confucius Institute at Malang State University is the oldest institution among 5 others. For 9 years, Confucius Institute at Malang State University has been carrying out many cultural activities but Mandarin learning is the center. Every year, this institute invites Indonesian university students to visit China, in Guilin, to learn basic Mandarin and join some cultural activities. This program held in summer, therefore, named Summer Camp program. This program introduces Chinese culture directly in China and gives an opportunity for participants to enjoy Chinese culture and meet Chinese people. 
Public diplomacy is one of the strategies used by a state to improve its image and create a common understanding with other countries. In general, public diplomacy is defined as diplomacy which focuses on the public in other countries. The public can act as an object or subject [17]. The public becomes an object when they become a target while on other case publics are involved in diplomacy activities. Although it focuses to influence the public in another country, the ultimate goal of public diplomacy is to influence their government. Public diplomacy works not in a hierarchical state-centric model but more operate in a network environment, aims to other country's public and promotes a positive aspect of the country [18]. Public diplomacy is also related to nation branding where public diplomacy activity, mainly in culture, contribute to the country's image development [19]. In a broader perspective, public diplomacy is also related to international public relations when it covers international communication by government and nongovernment actors [20]. Therefore, in the implementation, public diplomacy also collaborates with domestic society both in general as public or as the nongovernment organization [21].

Public diplomacy covers many fields, but usually, cultural activity is the most. It includes exhibition, scholarship, exchange and other activities related to culture. In public diplomacy, cultural diplomacy activities specifically involving the public and its main target is the public in other countries. The implementation and achievement of public diplomacy are divided into several levels [22]. The first is the introduction. At this level, public diplomacy focuses to introduce the country to the public in other countries. The second level is familiarity, where public diplomacy focuses on how the public in other country is getting accustomed to and getting to know about the country. At this level, public diplomacy usually starts to introduce unique things in his country. The third level is engagement, where the government is trying to tie up or strengthening ties by providing special programs such as scholarship or cultural exchange programs to get a positive impression. The last level is the influence. The main expectation of this stage is the emergence of understanding that is expected to affect public behavior and ultimately influencing the policies of the country. This study used public diplomacy's concept to explain how Summer Camp program influence participants perception toward China's image.

\subsection{Research Method}

This research was qualitative research. Qualitative research is not numeric data with research and data analysis did not use statistical methods [23]. Qualitative research usually uses inductive methods where the collected data were analyzed with the designation process for drafting the conclusions [24]. The data collected by an online survey through google form and interview. The informants of this research are 20 students of the department of international relations, the University of Muhammadiyah Malang who joined the Summer Camp program held by the Confucius Institute at the State University of Malang. The data analyzed was content analysis, where data is collected, categorized, and interpreted to obtain conclusions [25].

\subsection{Result and Discussion}

Confucius Institute at the State University of Malang held Summer Camp program every year to introduce Chinese culture to Indonesian student. The program held in Guangxi Norma University campus in Guilin city. It usually takes two weeks where it combines in-class and out-class learning. At the first week, participants have to join basic Mandarin class and some 
cultural lesson like calligraphy, paper cat arts, play traditional music instrument (Hulusi) and tai chi. While in the second week, participants visit some areas in Guilin to know more about Chinese culture directly.

This study focuses on the impact of the Summer Camp program to the image of China. According to the survey and interview toward participants, there is the result of this study which is divided into nine categories. (1) the perceptions about China before joining the program are China as a developed country in the economy, Communist country and less hospitable to Muslim. (2) the perceptions after joining the program are confirmation toward China's world economic position, a country with a beautiful natural landscape and the people appreciate the time and friendly. However, participants argue that there is a communication barrier when most people can not speak English. (3) Reasons for joining the program. Most of the participants said that they want to know more about China because they love to study East Asian country. (4) positive and negative impression during the program. Most participants said that they got a positive impression on the learning system, particularly to the material, cultural visit and other activities. While the negative impression more on the limited halal food since they are Muslims. They also felt that summer in China is hotter than the dry season in Indonesia. (5) The beneficiary from the program. All of the participants got many benefits such as experience, learning program, and networking. They were happy to learn Chinese directly in China and met Chinese people. (6) A future visit to China. All respondents said they are willing to visit China again if they have an opportunity. (7) The interest in Chinese studies. Most of the participants were inspired to study about China after joining the program. (8) The interest to write a thesis about China. Although most of them were intended to study about China, in the context of writing a thesis about China, they are not willing to do that. They said that they are interested to study about China but not for the thesis. (9) The interest to study in China. Most of the participants said that they willing to study in China for their master, however, 2 students said that they have another option.

The result shows how the impact of the activities of summer camp program against the image of China. There is a significant change in China's image in the context of their perception before and after joining the program, particularly on the relations with Muslim and about slouchy. They viewed Chinese people are friendly and clean. Meanwhile, the image of China as an economically developed country was confirmed. In general, almost all of the participants felt that they got many benefits from the program and it may inspire them to study about China or study in China for their post-graduate. However, love to study doesn't mean they like to make a research about China, particularly for their thesis's topic.

In the context of public diplomacy, the summer camp program seems to success to develop a positive image of China. All of the participants gave a positive impression and appreciation about China. It may cover to the first until the fourth level of public diplomacy when they are inspired to study about China or study in China in the future. However, one of the less influence is willing to write a thesis about China. Why the thesis becomes a matter? All of the participants are international relations students, where they have to write a thesis about international issues before graduate. Writing a thesis is not only about research or academic writing, but more, it is the way to express their opinion and argument to the topic that they wrote. It also means if more students write about China, it represents how their perception and opinion toward China in an academic way. It will give a different perspective than their personal experience and it may become literature for next research about China by other students. 


\section{CONCLUSIONS}

The summer camp program by the Confucius Institute at the State University of Malang have managed to turn and establish the positive image of China to the Indonesian students, particularly to the participants of the program. It also shows the success of China's public diplomacy in Indonesia. However, the number of participants may not significant if it compared with the Indonesian student's population. It also less significant to engage participants to do more specific about China, like writing a thesis about it. Therefore, it needs an improvement of the program to get wider participants or create the program in Indonesia. Chinese culture exhibition and performance may a good choice, but it also need to accompanied by the explanation about them since there is a language barrier. Finally, the summer camp program may succeed at almost public diplomacy's level, but it may need more improvement to complete the fourth level.

\section{REFERENCES}

[1] F. Hartig, Chinese Public Diplomacy, The Rise of the Confucius Institute. Oxon: Routledge, 2016.

[2] Wang. J, Soft Power in China: Public Diplomacy through Communication. New York: Palgrave MacMillan,2011.

[3] J. Gil, Soft Power and the Worldwide Promotion of Chinese Language Learning, The Confucius Institute Project. Bristol: Multilingual Matters, 2017.

[4] D. Sheng and R. A. Saunders, "Taking Up China: An Analysis of China's Rising Cultural Power and Global Promotion of Chinese Language," EAST ASIA. Summer 2006., Vol. 23, No. 2, pp. 3-33, 2006.

[5] D. Starr, "Chinese Language Education in Europe: the Confucius Institute," European Journal of Education., Vol.44, No.1, pp.65-82, 2006.

[6] Ling. L, "The Current State and Prospects of Chinese teaching in the United States," Chinese Education \& Society., Vol..49, pp. 376-384, 2016.

[7] F. Hartig, "Confucius Institutes and the Rise of China," Journal of Chinese Political Science/ Association of Chinese Political Studies., Vol.17, pp.53-76, 2012.

[8] F. Hartig, "How China Understands Public Diplomacy: The Importance of National Image for National Interest," International Studies Review., Vol.18, pp. 655-680, 2016.

[9] R. S. Zaharna, J. Hubbert, and F. Hartig, Confucius Institutes and The Globalization of China's soft power. Los Angeles: Figueroa Press, 2014.

[10] H. Craig, The Rhetoric of Soft Power: Public Diplomacy in Global Context. Lanham: Lexinton Books, 2012.

[11] Lee. A. W., "The Theory and Reality of Soft Power: Practical Approaches in East Asia", in Lee, S. J. and M. Jean (eds), Public Diplomacy and Soft Power in East Asia, New York: Palgrave MacMillan, 2011.

[12] Lin. J. Y., "A Study on the State of Development of Higher Education Confucius Institutes from Mainland China," Chinese Education \& Society., Vol.49, pp. 425-436, 2016.

[13] Wu. Y., "Review of the Confucius Institute's Strategy for Dissemination of Chinese Culture," Chinese Education \& Society., Vol. 49, pp. 391-401, 2016.

[14] R. Theo, and Leung, M. W. H., "China's Confucius Institute in Indonesia: Mobility, Friction, and Local Surprises,” Sustainability., Vol.10, pp. 2-15, 2018. 
[15] F. Ansori, "Pusat Bahasa Mandarin Universitas Al Azhar Indonesia: Refleksi dan Proyeksi Hubungan Sosial Budaya China-Indonesia," Jurnal Al-Azhar Indonesia Seri Humaniora., Vol.4, No.1, pp. 11-16, 2017.

[16] Thung, J. L., "Confucius Institute at Universitas Al Azhar Jakarta: The Unseen Power of China," Wacana., Vol.18, No.1, pp. 148-182, 2017.

[17] T. D. Effendi, Diplomasi Publik Jepang: Perkembangan dan Tantangan. Jakarta: Ghalia Indonesia, 2011.

[18] J. Mellisen, "The New Public Diplomacy: Between Theory and Practice", in J. Mellisen (ed), The New Public Diplomacy: Soft Power in International Relations ed J Mellisen. Hampshire and New York: Palgrave Macmillan. pp. 3-24, 2005.

[19] G. Scondi, Public Diplomacy and Nation Branding: Conceptual Similarity and Differences. Netherland: Netherlands Institute of International Relations 'Clingendael' and Antwerp University, 2008.

[20] G. J. Golan, Yang, S. U., and D. F. Kinsey, International Public Relations and Public Diplomacy: Communication and Engagement. New York: Peter Lang Publishing, 2015.

[21] K. Pisarska, The Domestic Dimension of Public Diplomacy: Evaluating Success through Civic Engagement, London: Palgrave Macmillan, 2016.

[22] M. Leonard, et al., Public Diplomacy. London: The Foreign Policy Center, 2002.

[23] C. Lamont, Research Methods in International Relations. London: Sage Publication, 2015.

[24] U. T. Silalahi, Metode Penelitian Sosial. Bandung: Refika Aditama, 2009.

[25] J. W. Creswell, Riset Desain: Pendekatan Kualitatif, Kuantitatif dan Mixed. Yogyakarta: Pustaka Pelajar, 2010. 